\title{
Cultural Branding as a Key in Positioning Schools: A Conceptual Model
}

\section{Hidayatun}

Semarang State University (UNNES)

email: hidaism@yahoo.com

\begin{abstract}
The increase of people's prosperity and education creates a change in their view about education and the need towards it. Consequently, their choice of educational institutions becomes more selective. On the other hand, the competition in this field becomes more viable due to the growth of the educational institutions. The management strategy should be evaluated. This paper discusses the interfaces between culture and school, especially those that refer to the branding. The study was carried out on a premise that creating a bond between the school and community is possible by adopting the culture in a formal education environment. This effort is expected to help schools to get a certain position in the community. Therefore, this study attempts to promote a conceptual model of cultural branding in schools and to reveal the reasons why the model becomes an effective marketing strategy in this era.
\end{abstract}

\section{Keywords:}

Branding, School culture, Positioning, Community bond

\section{Introduction}

A paradigm shift in the society that initially regards education institutions as a social activity into a business venture requires a change on the management strategy of the institution. Currently, many capital owners who do the business outside the education field begin to divert their investment in education (Banerjee 2017; Engerman, MacAllan, and Carr-Chellman 2017; Karppinen, Kallunki, and Komulainen 2017; Koustourakis, Asimaki, and Spiliopoulou 2017; Kusuma 2006). It indicates 
that some people make education as a business. Professionally, they manage education just like the way they do business. It is not surprising as they perceive education from its business value. On the other hand, many educational institutions apply traditional management and consider the education as a social institution (Areepattamannil, Freeman, \& Klinger 2017; Xie 2017). In fact, certain people still need these 'traditional' education institutions for a relatively low education fees. Unfortunately, both types of the institutions compete at the same time. Therefore, 'traditional' education institutions require a management and strategy change to survive and to thrive within this competition.

Along with the increasing of public awareness about the importance of qualified education, a low cost or even a free education fees is not a guarantee to choose the education services for their children (Ainscow \& Messiou 2017). Some people, especially those from the middle to upper economic levels, prefer to choose the trusted educational institutions with a high cost educational service rather than low cost or free educational institutions that are managed carelessly. In this case, education managers have to consider the need of their institutions. It is also considered reasonable that the education managers take anticipatory steps to prepare the skills to survive in this era. The change of the society's views should be accommodated by the committees of the educational institutions, so that the services offered to the society can be accepted (Barnatt et al. 2017; Díaz-Gibson, Zaragoza, Daly, Mayayo \& Romaní 2017; Nguyen 2017).

Lately, there is a new phenomenon in the education field. It is shown by the establishment of new educational institutions that are immediately recognized by the public interest as they carry out the vision of modern concept desired by the public. Moreover, this phenomenon may excel the existence of the early-established educational institutions.

This success is also supported by the skills of the professional managers. They often use business management approach in managing the 
education systems so that the public's needs become major considerations. The profile of the institution is described in a certain way through brand management that is acceptable for the public. A positive brand image will lead the prominent image of the educational institution. The educational fee is not an issue as long as the service complies with the quality provided by the institution. In fact, there is a wrong mindset which comes up to the society. People usually assume that qualified education is expensive.

\section{School Branding}

Branding is not a new phenomenon in business or academic fields. Actually, the branding concept has been used since the time of hunters using specific "brands" weapons of specific "brands" to succeed in hunting (Hampf 2011). The term of branding which has the same meaning as the purpose of the current branding was introduced to the public in the 16th century when Josiah Wedgwood, a potter from England, and Rose Bertin, a French fashion designer, marketed their products (Hampf 2011). Since that time, the concept of branding has grown rapidly both in theory and practice within the marketing attempts of various products and services.

Brand refers to a specific thing that is only possessed by an object (product or service) that distinguishes it from other objects. Brand is "a different name and/or symbol (such as logo, trademark, or package design) that is intended to identify the goods or services of either one seller or a group of sellers, and to distinguish those goods or services from competitors" (Ghodeswar 2008). Based on the cognitive aspect, Chang defines a brand as “a brand is a set of hooks that one's mind uses to organize his or her experience of a commercial offering” (Chang 2013). Businessmen and producers recognize the truth that brand helps them to increase the sales. Analogically, school branding attracts parents and students. From the customer point of view, Kapferer (2004) (Ghodeswar 2008) defines a brand as "the total accumulation of all his/her experiences, 
and is built at all points of contact with the customer". The product or service image creates indirect ties between producers and consumers that protect both sides from the competitors who attempt to provide a similar products or services. Brand may help consumers to identify a product or service and select them based on certain considerations.

Today, as the way people regard the education system, some educational institutions apply some strategic changes by creating a specific image (brand) to distinguish them from others and to attract public attention. Based on the research conducted by Mourad (Mourad 2011), brand and factors associated with it such as creating a brand image and school positioning contribute significantly to the decision-making for choosing schools. Therefore, understanding of the criteria in selecting an ideal school becomes a necessity for an educational institution manager. Good image of an educational institution will lead a signal to the public interest about the identity of the institution that will influence people for choosing the school.

Many people assume that a school is recognized due to the school ranking set by the government or the students' achievements in national examinations. Actually there are several factors that make a school is known and becomes people's choice. Besides these, Chang (2013) indicates that the school also established the brand as the culture of the school organization, learning atmosphere, and mindset or behavior developed at the school (Chang 2013). There are several factors that determine the building of a successful brand. As cited in Chang, some researchers such as (Jobber 2001; King 1991; Doyle 1989) claim that some important factors involving in building a successful brand are: quality, positioning, repositioning, communications, a long-term perspective, and internal marketing (Chang 2013). The relationship among these components is shown in Figure 1 below: 


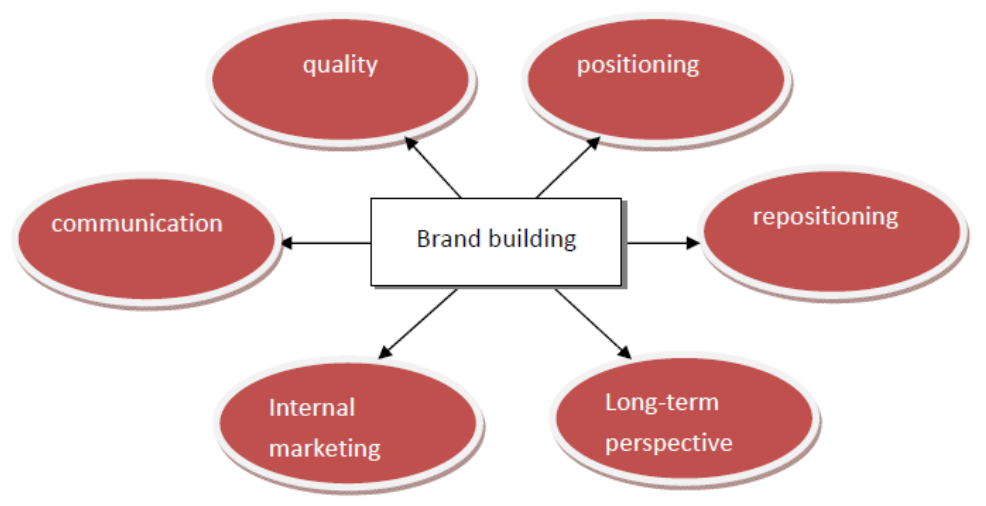

Figure (1) Components of brand building (Source: Chang 2013, 6)

Quality is a major element in the brand building. When a school has a high credibility and consistency of achievement it will have a high market share and profitability (Shaharudin 2010) (Shaharudin 2010). Positioning is an important aspect to build a successful brand. Some efforts to promote the positioning include: logos, institutions image, and service standards. Positioning is used by consumers to judge a brand in the market (Chang 2013). One of the examples of a successful positioning is Honda especially in motorcycles types. When people refer to a motorcycle, the one that comes first in public's minds is the brand. This is of course an advantage for manufacturers to push the marketing of their motorcycle product. Repositioning serves to maintain the brand by looking at the extent of how far the public receives their product as well as how the product accommodates the change of their interest. Communication is also needed to build public awareness about the brand as well as to reinforce the perception of it. All the components are tremendously useful to build an institution that is last longer but still remains to be a public choice. 


\section{The Culture in Organization}

The Indonesian constitution no. 20 of 2003 on National Education System defines the function and purpose of national education is as a reference in developing educational efforts in Indonesia. Article 3 of the Education Law states that "national education serves to develop and build the character and culture in context of the intellectual life of the nation which aims at developing students' potentials in order to become a man of faith who devote God Almighty, good attitude, healthy, knowledgeable, skillful, creative, independent, and become a democratic and accountable citizen". The national education goal is a reference to develop the quality of Indonesian people to be referred by each educational unit. Therefore, the formulation of national education objectives becomes the basis for the nation's culture and character development in Indonesian education system. School as the smallest unit in the national education system is an organization that is expected to be the place to cultivate and develop the culture. Talking about school culture will be closely related to the organizational culture theory.

It is stated by Davis and Newstrom (Mangkunegara 2005) that organizational culture is "the set of assumptions, beliefs, values, and norms that is shared among its members". Furthermore, Schermerhorn and Hunt in Mangkunagara define organizational culture as "the system of shared beliefs and values that develops within an organization and guides the behavior of its members"(Mangkunegara. 2005). The assumption, values, norms, or beliefs could be their own creation or an adaptation from the society that matches to their need. In line with Schein $(2005,113)$ in Mangkunagara $(2005,113)$ who argues that "an organizational culture learns to overcome external adaptation and internal integration problems that has been going well enough to be considered valid and taught to new members as a true perspective, thought and nuance in relation to the issue"(Mangkunegara 2005). 
Based on the explanations, organizational culture can be defined as a set of assumptions or beliefs, values and norms developed in organizational behavior used as guidelines for their members to resolve the external adaptation and internal integration problems. Similarly, Ouchi (Rivai 2012) defines organizational culture as symbols, ceremonies and myths that convey the principal values and beliefs of the employees' organizations. The culture serves as an ideological organization, traditions or beliefs that distinguishes an organization from others and embed life values in their structural framework.

Meanwhile, based on his research on organizational structure, Robbins proposes that there are seven main characteristics which constitute the cultural essence of an organization, namely : (1) innovation and risk taking, employees are encouraged to be innovative and be brave to take risks; (2) attention to details, employees are expected to run their precision, analysis, and take attention to detail; (3) result orientation, management is more focused on the results rather than on the techniques and processes used to achieve those results; (4) people orientation, the management decision considers the impact of the outcomes from personnel within the organization; (5) team orientation, work activities are organized in teams rather than individuals; (6) aggressiveness, all personnel are aggressive and competitive rather than relaxed; and (7) stability, organizational activities emphasize the retention status compared to the growth (Robbin 2011).

If we apply the idea of organizational culture into the school culture, it has an important role in school improvement. It is because the school culture is closely related to the behavior and habits of all members in the school about how they perceive problems and how they adapt to the society and make the school accepted in the society. Basically school culture provides a foundation and direction to the sustainability of effective and efficient education process. Thus, the substances of the school culture are behavior, values, attitudes, and ways of life of the school community that 
make school become a dynamic environment to facilitate their achievement of school goals. Nurkholis $(2003,45)$ enriches the illustrations of school culture as a pattern, values, norms, attitudes, rituals, myths, and habits that are formed in long process of school life. The basic categories in the school's organizational culture are formed of invisible conceptual matters consisting of values, philosophy, and ideology. These symbols interact with the visual symbols and expressions that consist of: (a) conceptual - verbal manifestations consisting of goals and objectives, curriculum, language, metaphors, organization history, organizational heroisms, and organizational structure; (b) the behavioral manifestations including rituals, ceremonies, teaching and learning processes, operating procedures, rules, rewards and sanctions, psychological and social encouragement, and interaction with parents and the community; (c) symbols - visual material manifestations that cover funding equipment facility, relics, finance, motto, and uniforms.

Culture is very important for any organization, including in school. As concluded by Robbin in Rivai (Rivai 2012), the organizational culture has an important roles as follows : (1) culture has a function to limits the firm: it creates distinctions between organizations; (2) culture gives identity to the organization; (3) culture improves the stability of social systems; (4) culture serves as the social bond that binds the organization. Organizational culture gives a standard for proper behavior. It is useful to guide and build the attitudes and behavior of school members.

Developing the organizational culture in school will give a 'special' identity that distinguishes one school to another. This is tremendously important because the implementation of school-based curriculum (SBC) allows the schools to develop their potential in accordance with the needs of society. Moreover, the culture is able to create strong bond among stakeholders in the school. Therefore, culture may become a power to develop the school. Further, Deal in Rivai (Rivai 2012) says that the school 
which has a strong culture will have the following characteristics: (1) shared value and a consensus about "how we settle things around; (2) headmaster as a hero who embodies the principal values; (3) different rituals that divide trust widely; (4) employees as situational heroes; (5) ritual acculturation and cultural renewal; (6) significant rituals to celebrate and change the principal values; (7) a balance between innovation and tradition, between autonomy and control; (8) broad participation in cultural rituals.

School culture is concerned with school members' view the characteristics of school culture. The comprehension to this idea becomes very important for school members to distinguish between school culture and job satisfaction. Culture binds all members in the school community to act the same the consideration of their identity. As stated by Ansar \& Masaong in Arifin (2011, 186), school culture has four characteristics: (a) school culture is specific (distinctive) because each school has their own history, pattern of communication, systems and procedures, vision and mission; (b) school culture is fundamentally stable and usually changes when there is a threat of "crisis" from other schools; (c) school culture has its own history either implicitly or explicitly; and (d) school culture is a representative symbol that underlies the beliefs and values of school.

Certain moments occur internally and externally in a school can change the school culture. Although school culture tends to be consistent, in some cases such as market demand, new technology, policy changes, and other factors, may lead to the change it. It is not something that needs to be debated, because a good school culture must be marketoriented, service users or customers. Sudarwan in Arifin (2003) noted that the primary characteristic of school culture are: (a) the membership of the school community are innovative and ready to take risks; (b) the school community, especially the principal, teachers and staffs, are able to act quickly and appropriately; (c) the action of the school community, especially school principal and teachers, action is more important than 
verbal actions; (d) job focus of the principals and teachers are result oriented, while techniques and processes are merely instruments; (e) people or customer oriented both internal and external; (f) synergy in teams, (g) high responsiveness and aggressiveness in work; (h) the regularity and consistency of the policies; (i) the reliability, vision, mission, objectives, policies, and their implementation; and (j) accountability and sustainability of the program.

How to learn culture in an organization? Robbins states that culture is transmitted through some ways, most likely is in the forms of story, rituals, material symbols, and language (Robbin 2011). The example of the story to motivate all members of the organization is the story about the founder of the organization. Ritual is a series of repetitive activities that express and reinforce the basic value of the organization about the important goal, most important people, and the one that can be excluded in the organization. One of the company's famous ritual is singing WalMart. Initiated by its founder, Sam Walton, as a way to motivate and unite the workers, "Gimme a W, gimme an A, gimme an L, gimme a sqiiiggle, gimme a M , A , R , T ! " ( Give me a W, give I A, give me a L, give me dash, give me the $\mathrm{M}, \mathrm{A}, \mathrm{R}, \mathrm{T} !)$ become a ritual that unites the company employees of Wal-Mart. Sam Walton reinforced the belief of the importance of employees to the success of his company.

\section{Branding Schools through Society's Culture}

In this competition era, branding becomes a very important aspect of any organization's management strategy, including schools. The phenomenon nowadays is that schools do not only provide the tangible services for the consumer. However, schools also serve the intangible services for the consumers. According to Lovelock \& Wirtz (2011) in Chang (Chang 2013) these services are process-orientated, including people processing (students' physical entrance to the school 
field), possession processing (students' knowledge and skill possessions), mental stimulus processing (students' ethical standards establishment and maintenance), and information processing (other related intangible form of service). Only ownership transfers does not include in the service. Business programs, services provided by school are also characterized and assessed of their quality after consumption (Chen 2008).

Since education has become a worldwide commodity, educational administrators regard students as customers, representing major stakeholder group in an educational the line of inquiry these days (Segev et al. 1999). The service that is provided by schools should be based on consumer orientation. Therefore, the decision-making process in schools must accommodate their need.

Schools cannot stand alone without society. They have a strong relationship that develops naturally. Schools do not occur in a vacuum or isolation; it happens in the society and takes some advantages from it. On the other side, the society also needs schools to help them develop their children. It is stated by Daramola (1985) that education in school is "seen as a means of cultural transmission from one generation to another within a society. Society is defined as the whole range of social relationships of people who live in a certain geographical area and have a sense of belonging to the same group". So it can be said that there is a mutual relationship between schools and society (Daramola 1985).

There are many schools in the societies that compete to be their choice. They compete to create an image that their school does the best. What they usually consider is about the school rankings. All efforts are made to achieve a higher ranking than others. Each school creates a brand image associated with the school. However, the brand is not merely only about the school's ranking but also about its culture, atmosphere, and mindset (Chang 2013). Then, placing a school at a certain position in the society would be a beneficial advantage for schools to market their services 
in this fierce competition. Ghodeswar (2008) states that positioning is related with "creating of the brand perception in the mind of customers, achieving differentiation apart from brands or competitors' offerings and meeting to the consumers' needs". Positioning makes consumers (society) have a clear insight about school brand. It also helps school get an attention of the society (Ghodeswar 2008)

There are several ways to do positioning for a school. Positioning through academic quality is the best way in branding a school. Its consistence and credibility is usually expected in consumers' minds (Chang 2013); that is why the brands with higher quality achieve higher market share and higher profitability (Chen 2008; Shaharudin 2010). However, positioning quality-based school is not easy and quite complex. It takes a lot of many resources - high budget, an important attention, time consuming, planned actions, and others - to be aware of. Positioning with specific reference to the school branding can be done through the adoption of society's culture into school culture. Here, school functions as a society agent to inherit and develop society's culture to their generation. Thus, school establishes a mutual relationship with the society to maintain their norms, values, and cultures.

Positioning school through cultural branding has several advantages comparing to other branding strategy. Chang (2003) noted that (e.g. Gregory \&Munch 1996; Shulruf, Hattie, \& Dixon 2011; Wagner III 1995) that Asians concerns with their group and family, in contrast to the more individualoriented of Westerners. Asians pay more attention to the collectivists who have a great emphasis on the importance of groups and family and think more deeply about "we", in contrast to more individualistic westerners who mostly regard themselves as an individual. Consequently, for an Asian student, choosing a school tends to be a family mission or even society rather than personal mission. Therefore, implementing cultural branding will create a cultural bond between school and society. That is because 
"people tend to like people (and also organizations including school) with whom they share common traits. The same idea applies to the consumer brand interactions" (Hwang 2012). Branding through culture is also simpler and less budget-consuming. School managers need to map out which the society's norms, values, or cultures should be adopted in school culture and plan activities to make them be a school habit that eventually evolves into school behavior.

\section{Conceptual Development}

As noted earlier, the study focuses on some factors in society school relationship related to cultural branding models - culture and its representation in cultural branding, brand love, and emotional attachment - and their impact on personal commitment (loyalty). In particular, the proposed model illustrates:

- The cultural representation of society in cultural branding developed by school;

- The positive impact of cultural concept on emotional attachment, brand love, and loyalty; and

- The positive effects of brand love and emotional attachment to consumer loyalty in the context of luxury fashion brands (see Figure 2).

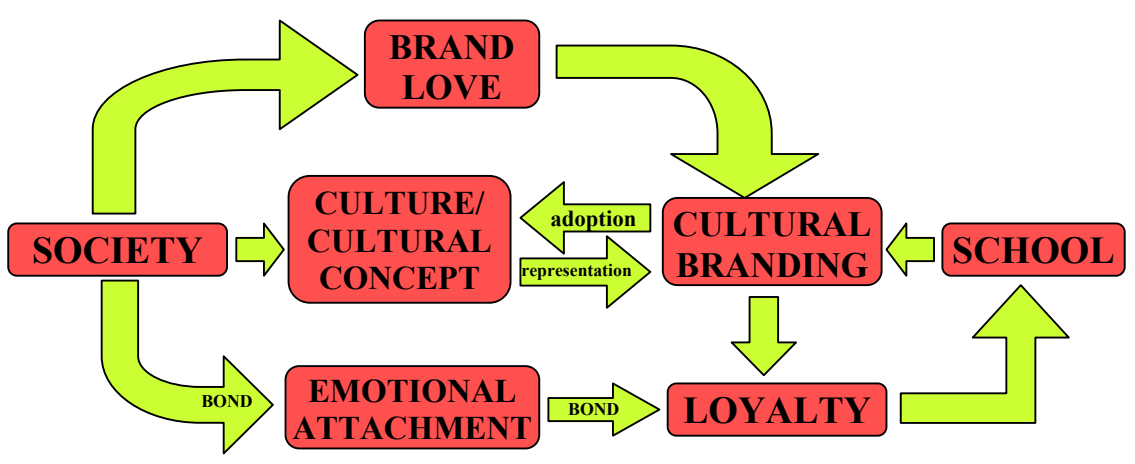

Figure (2) Conceptual framework 
The figure shows that there is a mutual relationship between school and society indirectly. The two sides relate through school culture that is represented from society's culture and school with society by developing a branding strategy adopted from society's culture. As cultural branding developed by school introduces a representation of society's culture, it will potentially create a 'special' relationship between society and school that are manifested into brand love. If people believe that education in school really serves as a means of cultural transmission from one generation to another for maintaining it, there will be a personal bond called the cultural bond. Hence, the following concepts are proposed: firstly, public perception about the relationship between cultural-concept and cultural brands developed by school will increase their brand love and emotional attachment to school. After a period of time, since culture changes into school habit and behavior, when society believe that school programs are sustainable action to maintain their norms, values, or cultures, brand love and personal attachment turn into loyalty. Loyalty is a relational result expected by the schools in this branding matter as Oliver (1999) in Hwang (2012) argued that "brand loyalty, the principle of brand equity, is a key indicator of the sustainability of a brand because being loyal to a brand keeps its consumers tending to switch to competitive brands, even when the competitors offer more benefits" (Hwang 2012).

Thus, the concept can be generated into following secondly, the commitment and consistency of school to maintain and preserve society's culture continuously through school branding will increase their loyalty to the school.

\section{Conclusion}

This paper discusses the cultural branding model for creating school branding based on the literature review and case study. Schools need to create a strong branding to survive and compete with others. Since the society 
is the consumer and user of schools' education service, positioning in society can also provide benefits for the school. The suggested positioning strategy proposed in this paper is called 'cultural branding' which has some related factors: culture and representation in cultural branding, brand love, and emotional attachment - and its impact on personal commitment (loyalty). This cultural branding requires a consistency and commitment to maintain and preserve the society's culture with the aims of supporting the school to gain loyalty from the society. 


\section{References}

Ainscow, M., \& Messiou, K. (2017). Engaging with the views of students to promote inclusion in education. Article in Press. Retrieved from https: / / www.scopus.com/inward/ record.uri? eid=2-s2.0$85038371959 \&$ doi $=10.1007 \% 2$ fs10833-017-9312-1\&partnerID $=$ 40\&md5=bb7b2bfd1908b9bd159e6a2673a1c9a4

Areepattamannil, S., Freeman, J. G., \& Klinger, D. A. (2017). A qualitative study of Indian and Indian immigrant adolescents' perceptions of the factors affecting their engagement and performance in school. Article in Press. Retrieved from https://www.scopus.com/inward/record. uri?eid $=2$-s2.0-85038375084\&doi $=10.1007 \% 2$ fs 11218-017-9420z\&partnerID $=40 \& \mathrm{md} 5=$ cce8a5a75b71d6dcb6050af8ec7816fe

Banerjee, N. (2017). Effects of Teacher-Student Ethnoracial Matching and Overall Teacher Diversity in Elementary Schools on Educational Outcomes. Article in Press. Retrieved from https://www.scopus.com/inward/ record.uri?eid $=2$-s2.0-85038354511\&doi $=10.1080 \% 2 \mathrm{f} 02568543$. 2017.1393032\&partnerID $=40 \& \mathrm{md} 5=9228732 \mathrm{~b} 347 \mathrm{c} 680 \mathrm{efe} 2 \mathrm{~b} 2 \mathrm{dc}$ 3eb4ceea1

Barnatt, J., Gahlsdorf Terrell, D., D’Souza, L. A., Jong, C., Cochran-Smith, M., Viesca, K. M., ... Shakman, K. (2017). Interpreting Early Career Trajectories. Educational Policy, 31(7), 992-1032. https:// doi.org/10.1177/0895904815625286

Chang, Y. Y. C. (2013). Does School Branding Matter in Secondary Education? Chen, L. H. (2008). Internationalization or international marketing? Two frameworks for understanding international students' choice of Canadian universities. Journal of Marketing for Higher Education, 18 (1), 1-33.

Daramola, C. O. (1985). Education and Society: What Type of Relationship? Ilorin, Nigeria: University of Ilorin.

Díaz-Gibson, J., Zaragoza, M. C., Daly, A. J., Mayayo, J. L., \& Romaní, J. R. (2017). Networked leadership in Educational Collaborative Networks. Educational Management Administration and Leadership, 45(6), 1040-1059. https://doi.org/10.1177/1741143216628532

Engerman, J. A., MacAllan, M., \& Carr-Chellman, A. A. (2017). Games for boys: a qualitative study of experiences with commercial off the shelf gaming. 
Article in Press. Retrieved from https:/ /www.scopus.com/inward/ record.uri?eid $=2$-s2.0-85038126946\&doi $=10.1007 \% 2$ fs 11423 017-9548-8\&partnerID $=40 \& \mathrm{md} 5=\mathrm{c} 5297 \mathrm{~d} 2 \mathrm{f} 9601 \mathrm{a} 178 \mathrm{c} 19 \mathrm{~b} 7005 \mathrm{~d}$ 26baab1

Ghodeswar, B. M. (2008). Building Brand Identity in Competitive Markets: a Conceptual Model. Journal of Product \& Brand Management, 17 Number, 4-12.

Hampf, A. \& K. L. R. (2011). Branding: The Past, Present, and Future: A Study of the Evolution and Future of Branding. Finland: Hanken School of Economics.

Hwang, J. \& J. K. (2012). The role of emotional aspects in younger consumer-brand relationships,. Journal of Product \& Brand Management, Volume 21, 98-108.

Karppinen, S., Kallunki, V., \& Komulainen, K. (2017). Interdisciplinary craft designing and invention pedagogy in teacher education: student teachers creating smart textiles. Article in Press. Retrieved from https: / / www.scopus.com/inward / record.uri? eid=2-s2.085039058110\&doi=10.1007\%2fs10798-017-9436-x\&partnerID = 40\&md5 $=82 \mathrm{dc} 970 \mathrm{~d} 415756 \mathrm{afd} 4 \mathrm{ba} 98299 \mathrm{a} 23 \mathrm{edce}$

Koustourakis, G., Asimaki, A., \& Spiliopoulou, G. (2017). Cultural activities and the family's "institutionalised" cultural capital: the case of native and immigrant primary school pupils. Article in Press. Retrieved from https:/ / www.scopus.com/inward/record.uri?eid=2-s2.0$85037972425 \&$ doi $=10.1080 \% 2 f 14681366.2017 .1412340 \&$ partner $\mathrm{ID}=40 \& \mathrm{md} 5=8 \mathrm{~d} 3 \mathrm{a} 1 \mathrm{f} 7 \mathrm{cc} 8 \mathrm{c} 67062318 \mathrm{ae} 02 \mathrm{a} 61240 \mathrm{ded}$

Kusuma, I. M. (2006). Manajemen Pendidikan di Era Reformasi,. Jurnal Pendidikan Penabur, No.06/Th.V, 76-86.

Mangkunegara. (2005). Perilaku dan Budaya Organisasi. Bandung: Refika Aditama.

Mourad, M. (2011). Role of brand related factors in influencing students' choice in Higher Education (HE) market, Int. Management in Education, 5, 258-270.

Nguyen, C. D. (2017). Beyond the school setting: language teachers and tensions of everyday life. Teachers and Teaching: Theory and Practice, 23(7), 766-780. https://doi.org/10.1080/13540602.2016.127605 4 
Rivai, M. (2012). Education Management Analisis Teori dan Praktik. Jakarta: Raja Grafindo Perkasa.

Robbin, S. P. dan T. A. J. (2011). Perilaku Organisasi Translated by Angelica, D. Jakarta: Salemba Empat.

Shaharudin, M. R. (2010). The relationship between extrinsic attributes of product quality with brand loyalty on Malaysia national brand motorcycle/scooter. Canadian Social Science, 6 (3), 170-182.

Xie, Z. (2017). Research on the application of Chinese paper-cut art in primary and secondary school art education. Boletin Tecnico/ Technical Bulletin, 55(20), 541-547. 